REGIONAL STATISTICS, 2013, VOL. 3: 57-78 DOI: 10.15196/RS03104

CSILLA OBÁDOVICS ${ }^{\text {a) }}$

\title{
Regional level analysis of the population by real data and projections in Hungary
}

\begin{abstract}
Population projections of László Hablicsek (1953-2010) have major scientific contribution to understanding the demographic processes of Hungary; its social and economic usefulness cannot be questioned. Although, trends of the past ten years indicate the need for some corrections. The present analysis shows that the population estimation was very close to reality in the past ten years. There was no significant difference between the estimated and real data; only last year's data show some alteration. However, the projections for smaller territorial scales are in need for serious corrections. In recent years, regional disparities in the country rather increased. The migration towards large cities, moving from undeveloped areas to more developed ones raise dissonance among regions. The population concentration proved to be stronger than the forecast, and the analysis showed, that the regional concentration of the population as well as the loss of population has further reinforced the unfavourable position of underdeveloped regions at micro-regional level. Immigration from abroad further enhances regional differences, since the immigrants presumably do not prefer rural, disadvantaged areas, they most probably favour economically developed micro-regions which are close to big cities. The observed changes in the socio-economic environment require corrections in the demographic projections, which is a natural need of the professional audience as well as actors in social policy.
\end{abstract}

Keywords: long-range population projection, demographic trends, economic development.

László Hablicsek, expert of population projections in the HCSO Demographic Research Institute, was the author of numerous demographic studies and the leader of many researches. He is credited with the long-range population projection and estimation in Hungary. He performed the population estimation on the basis of the 2001 census data and projected the changes in the population number by different projection variants until 2050. Later, in 2006, he updated and corrected the model on the basis of the 2005 microcensus. He applied the Cohort component method $^{2}$, in the course of which he took into account demographic phenomena directly influencing the population number, such as fertility, mortality and migration.

a) Faculty of Economics, University of West Hungary, H-9400 Sopron, Erzsébet út 9, Hungary, E-mail: csilla.obad@gmail.com

2 For more details about the method see H. Richter Mária (2002). 
His projections made in the past decade will still be in use for long. Hablicsek established the database for regional population, qualification and activity/inactivity projections, the so-called PQW (population, qualification, workforce) system. This is built up by the projections of the following factors: population, educational attainment, economically active population, employed, jobseekers, economically inactive population, full-time students, people rearing child(ren), pensioners, dependents and other inactive people.

The present study aims at reviewing the results of the Hungarian population projection procedures in commemoration of the recently passed away scientific researcher. On the basis of some analyses, studies, research reports and articles, as well as the data of HCSO, the study investigates how the population of Hungary changed in the last forty years and then compares the real data with the estimated ones on regional, county and, finally, on micro-regional level.

In addition to the country-level population projections, the study analyses the relation between micro-regional demographic inequalities and socio-economic development with the help of multivariable statistical methods using the data of micro-regional population projections as well.

\section{Population projection variants on country level}

Population projection is in fact an estimation method, in the course of which the number of births, the number of deaths, migration processes and the changes in life expectancy at birth are taken into account.

The population of Hungary increased until 1980, then, a slow decrease started. The population number grew by $4 \%$ between 1970 and 1980, while it fell by $4 \%$ between 1980 and 1990. Figure 1 presents the changes in the number of births and deaths as well as the difference between them. The figure well demonstrates that the natural increase of the population turned to natural decrease in 1980.

Birth and death rates between 1901 and 2000

Figure 1

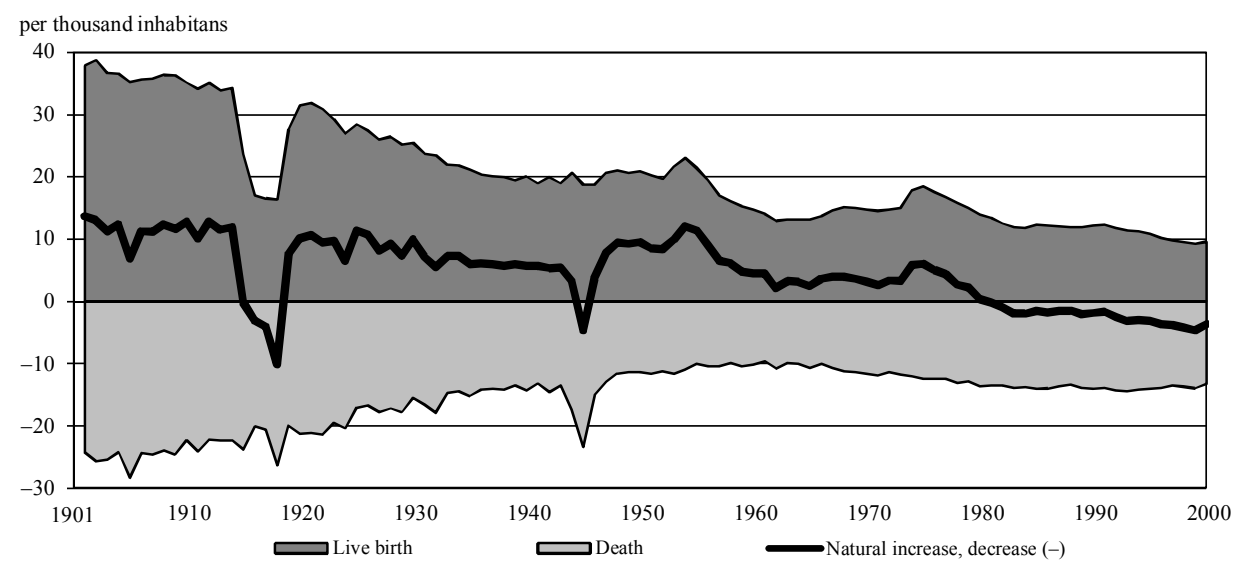

Source: nepszamlalas2001.hu 
László Hablicsek prepared the projections in different kinds of variants. The variants were prepared as a function of demographic processes taking into account their different changes in the future. He made the estimations for genders, age cohorts, educational attainment, economic activity, but, in the practice, there are examples for projecting the number of the elderly, the pensioners, or even the number of the school-age population. ${ }^{3}$

In line with the different trends in the number of children, life expectancy at birth and balance of migration ${ }^{4}$, the Hablicsek projection was prepared in the following variants: (1) baseline variant, (2) young variant, (3) old variant, (4) low and (5) high variant and (6) European variant. This latter variant shows demographic trends targeted on a shorter run, thus, it is not covered by the present study (Hablicsek 2009). The basic characteristics of indicators relating to each projection variant are included in Tables 1 and 2, while Figure 2 compares the population estimations calculated on the basis of the different variants on country level.

Table 1

Components of population projection variants

\begin{tabular}{l|c|c|c|c}
\hline Projection variants & $\begin{array}{c}\text { Averag number of } \\
\text { children }\end{array}$ & $\begin{array}{c}\text { Average age of } \\
\text { women at childbirth }\end{array}$ & Life expectancy & $\begin{array}{c}\text { Balance of } \\
\text { international } \\
\text { migration }\end{array}$ \\
\hline Baseline & medium & medium & medium & medium \\
Old & low & low & high & low \\
Young & high & high & low & high \\
Low & low & low & low & high \\
High & high & high & &
\end{tabular}

The baseline variant seems to represent the real future. The low variant corresponds to the pessimistic, while the high variant to the optimistic estimation. The young and the old projections show only slight deviation from the baseline variant. The difference between the young and the old variants is also only half million persons (Hablicsek 2009).

Table 2

Characteristics of population projection variants

\begin{tabular}{l|c|c|c|c}
\hline Category & $\begin{array}{c}\text { Average number of } \\
\text { children, child }\end{array}$ & $\begin{array}{c}\text { Average age of } \\
\text { women at childbirth, } \\
\text { years }\end{array}$ & $\begin{array}{c}\text { Life expectancy } \\
\text { men/women, years }\end{array}$ & $\begin{array}{c}\text { Balance of } \\
\text { international } \\
\text { migration, persons }\end{array}$ \\
\hline Low & 1.3 & 29 & $72.6 / 80.8$ & 8000 \\
Medium & 1.5 & 31 & $75.3 / 83.0$ & 15000 \\
High & 1.8 & 33 & $78.0 / 85.2$ & 22000
\end{tabular}

Source: Hablicsek (2009).

In the baseline variant, medium number of children (fertility rate grows from 1.3), medium life expectancy (75.5 years for men, 82.5 years for women) and medium migration, i.e. an annual surplus of 14-15 thousand persons on the long run are assumed. 
In the higher version of the baseline variant, an annual international migration surplus of 30 thousand persons is assumed on the long run along with low life expectancy, which is however slightly higher than at present, and medium number of children.

In the low version of the baseline variant, the number of children is also medium, life expectancy is high ( 82 years for men and 88 years for women) as opposed to the low balance of migration. (Due to the emigration/further migration of foreigners having immigrated to Hungary, the surplus of the migration balance decreases to 7 thousand persons (Polónyi-Tímár 2006).)

In the young variant, the number of children is high (fertility rate increases from 1.3 to 1.6 and then to 1.9), life expectancy is low, while migration is high. Finally, in case of the old variant, each component is reversed, i.e. low number of children (fertility rate remains 1.3), high life expectancy and low migration are assumed.

According to the estimation of Hablicsek (2001), if the baseline variant was associated with a positive balance of migration of 40 thousand persons every year (47 thousand immigrants, 7 thousand emigrants every year), the population number would steadily remain 10 million even along with a relatively low fertility and a slowly increasing life expectancy.

Figure 2

Change in the number of population according to the different projection variants

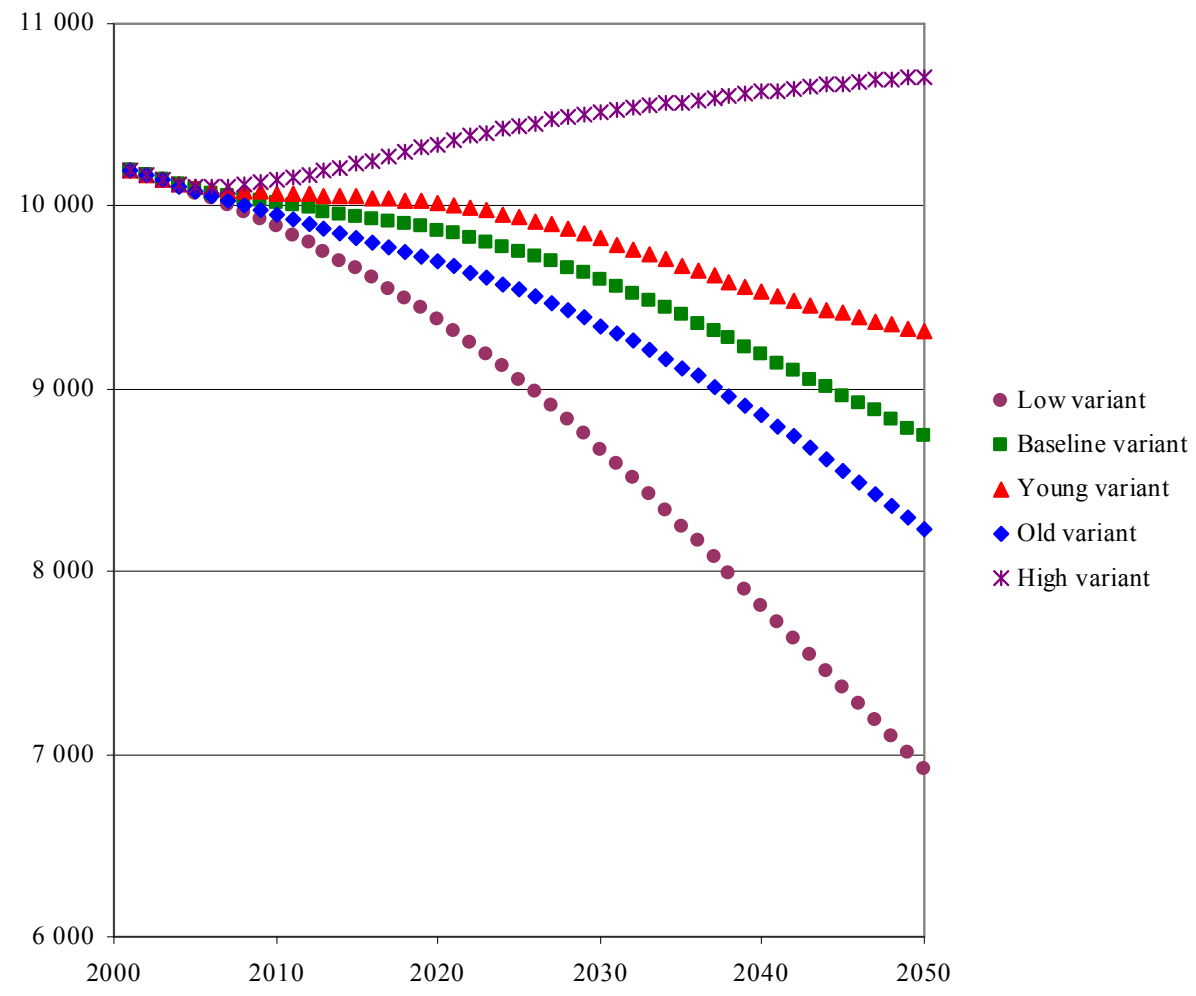

Sources: Own calculation based on the data of HCSO 
The long-range projection of Hablicsek analyzed in my present study is based on the census 2001. The 10 years since that time is not a really long period in this context, however, it is worth examining whether there is any difference, and if yes, how large the difference is between the projection and the real population data.

Out of the different population projection variants, the baseline variant approximated reality the most accurately for the past ten years. However, it could not be foreseen in 2001 that, by the end of the decade, the economic crisis would exert its effect on demographic processes as well, so a slightly larger difference could be observed between the projection and the real data of the last year (Figure 3).

In addition to the economic crisis, modifications in social allowances and changes in tax laws and family support could also influence our indicators of natural population movement. We have to be of course aware that measures aiming at increasing childbearing intention may change the trend towards another variant, or unfavourable economic processes may result in approaching just the old variant. All these effects are of course only probable, and there are only speculations about their extent.

Population number and projected population number between 2001 and 2011

(baseline variant)

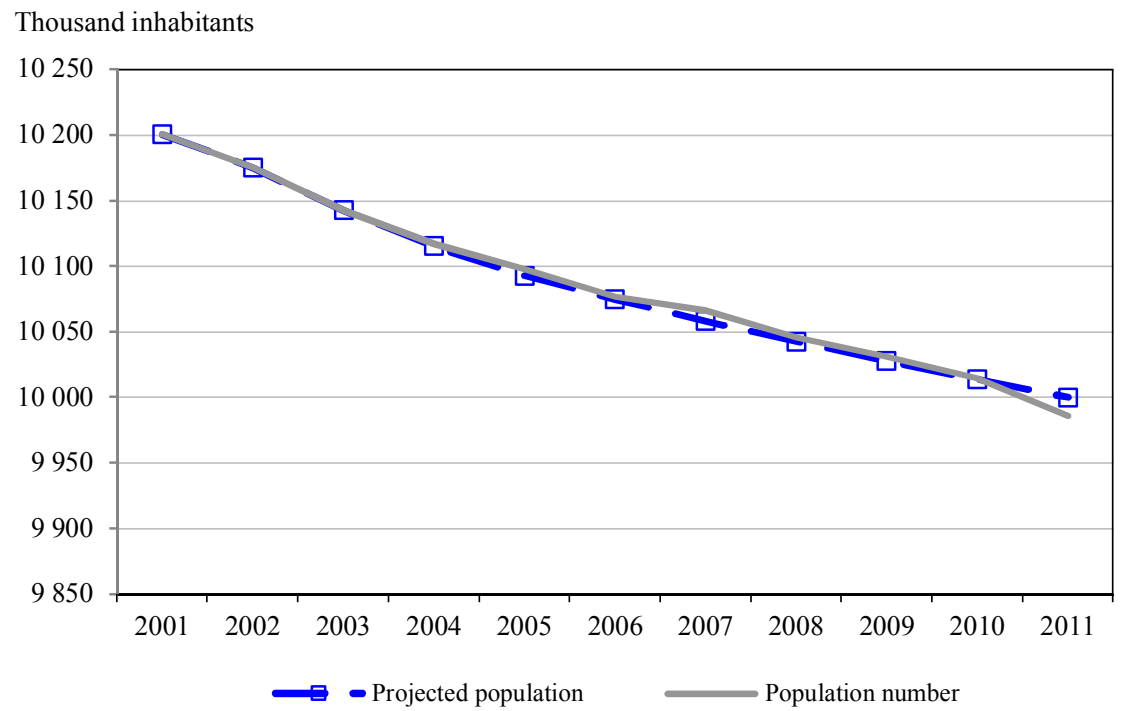

Sources: Own calculation based on the data of HCSO.

It is well demonstrated by the figure that the values of estimated and real population numbers are very close to each other on the time-base. When subjecting the two curves to statistical control as well, the results can be considered very good. (The relative dispersion of the residua is 5.5\%.) Except for three data points, each estimated value is within the confidence interval, the data of 2007 showed somewhat lower population number than the real data, while the estimation for 2011 was somewhat higher than the real data, i.e. the real data of these two years showed an upward and a downward deviation, respectively from the estimations. This deviation is presumably not the result 
of internal coherences in demographic processes, but it can be much more attributed to the social policy, the support system and the economic changes.

\section{Regional projections}

In regional breakdown, the results are not nearly so clear. Demographic processes show great diversity just as socio-economic processes. For that very reason, population projection made only on country level is not sufficient, it is necessary to present the differences within the country as well. The regional, county-level and micro-regional projections prepared by László Hablicsek also come from this recognition making a good step forward in demographic projections and in demonstrating the connections between social and economic policies.

According to projections, Hungary will probably record an $8.3 \%$ population loss by 2021 compared to 1980 . A special attention is paid to regions diverging from the national trend in negative or positive direction (Table 3).

Table 3

Population projection and change in population size between 1980 and 2021 by regions

\begin{tabular}{|c|c|c|c|c|c|c|c|c|}
\hline Year & $\begin{array}{c}\text { Southern } \\
\text { Great Plain }\end{array}$ & $\begin{array}{l}\text { Southern } \\
\text { Trans- } \\
\text { danubia }\end{array}$ & $\begin{array}{l}\text { Northern } \\
\text { Great Plain }\end{array}$ & $\begin{array}{l}\text { Northern } \\
\text { Hungary }\end{array}$ & $\begin{array}{l}\text { Central } \\
\text { Trans- } \\
\text { danubia }\end{array}$ & $\begin{array}{l}\text { Central } \\
\text { Hungary }\end{array}$ & $\begin{array}{l}\text { Western } \\
\text { Trans- } \\
\text { danubia }\end{array}$ & Country \\
\hline $1980^{\text {a) }}$ & 1464658 & 1059160 & 1590901 & 1400079 & 1120956 & 3033056 & 1040653 & 10709463 \\
\hline $1990^{a)}$ & 1397627 & 1015783 & 1546612 & 1323508 & 1110302 & 2966523 & 1014468 & 10374823 \\
\hline $2001^{\text {a) }}$ & 1380383 & 997668 & 1563709 & 1302833 & 1116721 & 2831095 & 1007860 & 10200269 \\
\hline $2006^{\mathrm{b})}$ & 1347294 & 970700 & 1533162 & 1261489 & 1108124 & 2855670 & 1000142 & 10076581 \\
\hline $2011^{\mathrm{c})}$ & 1320040 & 943002 & 1503758 & 1221183 & 1098640 & 2917461 & 993030 & 9997114 \\
\hline $2016^{\mathrm{c})}$ & 1292479 & 915471 & 1473083 & 1182618 & 1085648 & 2974491 & 982664 & 9906454 \\
\hline $2021^{c)}$ & 1268030 & 889153 & 1446569 & 1148000 & 1072055 & 3026871 & 972378 & 9823056 \\
\hline \multicolumn{9}{|c|}{ Population number (previous year $=100 \%$ ) } \\
\hline \multicolumn{9}{|l|}{1980} \\
\hline 1990 & 95.4 & 95.9 & 97.2 & 94.5 & 99.0 & 97.8 & 97.5 & 96.9 \\
\hline 2001 & 98.8 & 98.2 & 101.1 & 98.4 & 100.6 & 95.4 & 99.3 & 98.3 \\
\hline 2006 & 97.6 & 97.3 & 98.0 & 96.8 & 99.2 & 100.9 & 99.2 & 98.8 \\
\hline 2011 & 98.0 & 97.1 & 98.1 & 96.8 & 99.1 & 102.2 & 99.3 & 99.2 \\
\hline 2016 & 97.9 & 97.1 & 98.0 & 96.8 & 98.8 & 102.0 & 99.0 & 99.1 \\
\hline 2021 & 98.1 & 97.1 & 98.2 & 97.1 & 98.7 & 101.8 & 99.0 & 99.2 \\
\hline \multicolumn{9}{|c|}{ Population number $(1980=100 \%)$} \\
\hline 1980 & 100.0 & 100.0 & 100.0 & 100.0 & 100.0 & 100.0 & 100.0 & 100.0 \\
\hline 1990 & 95.4 & 95.9 & 97.2 & 94.5 & 99.0 & 97.8 & 97.5 & 96.9 \\
\hline 2001 & 94.2 & 94.2 & 98.3 & 93.1 & 99.6 & 93.3 & 96.8 & 95.2 \\
\hline 2006 & 92.0 & 91.6 & 96.4 & 90.1 & 98.9 & 94.2 & 96.1 & 94.1 \\
\hline 2011 & 90.1 & 89.0 & 94.5 & 87.2 & 98.0 & 96.2 & 95.4 & 93.3 \\
\hline 2016 & 88.2 & 86.4 & 92.6 & 84.5 & 96.9 & 98.1 & 94.4 & 92.5 \\
\hline 2021 & 86.6 & 83.9 & 90.9 & 82.0 & 95.6 & 99.8 & 93.4 & 91.7 \\
\hline
\end{tabular}

Source: Own calculation based on VÁTI TEIR.

a) Real data. b) Further calculation. c) Projection. 
The most drastic population loss is expected in Northern Hungary and Southern Transdanubia. The population of Southern Great Plain will decrease more than in the whole country, and its annual decline will slightly exceed the national average. A positive deviation can be observed in case of Central Hungary and Central Transdanubia. In these two regions, stagnation or even a population increase could be observed in some periods. Central Hungary is the only region of Hungary, where, compared to 1980 , the population number practically will not change by 2021 , and since the new projection in 2006, the population has been increasing. It must be mentioned however, that this region comprises Budapest as well. Despite the considerable population loss in Budapest, a positive change is probable in the total population size of the region, which can be attributed to the very significant development, the population attracting ability, the favourable age-structure and the high fertility rate of the agglomeration. Although there was some fluctuation at the beginning of the observed period, between 1990 and 2001, the population loss was here the largest in the country, but this negative peak was largely offset by the positive population balance in the following period.

The population dynamics of Central and Western Transdanubia is more favourable than in the whole country. The following figure presents the comparison of the estimated population number with the real population data for the years 2006 and 2011.

Difference between real and projected population* as a percentage of

Figure 4 the population by regions

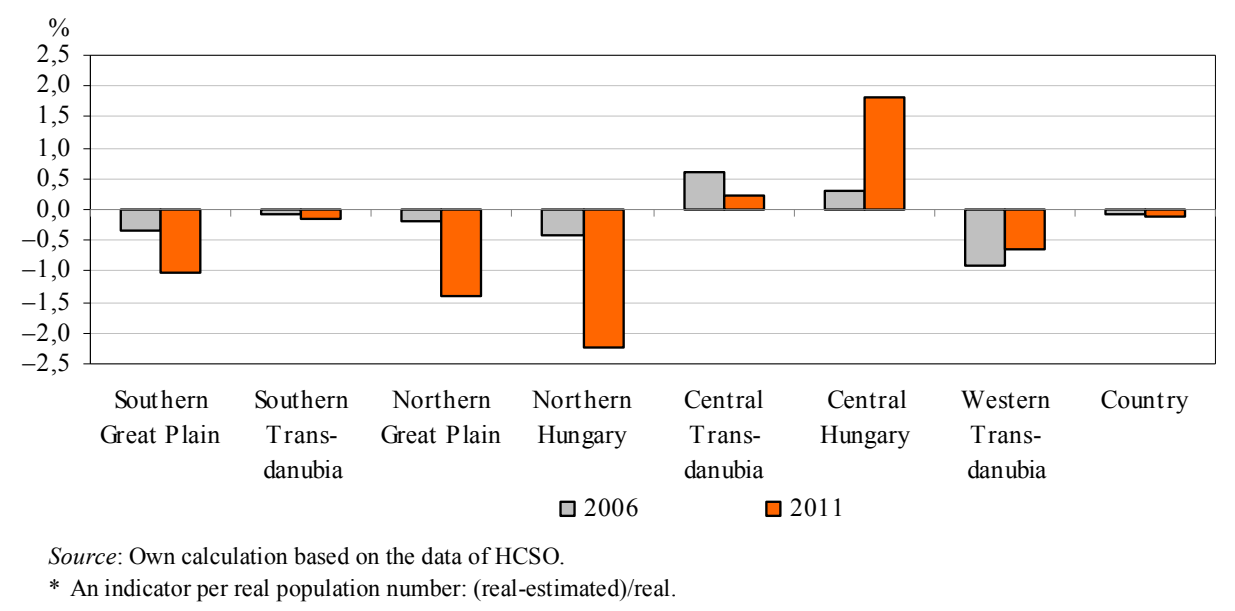

The divergence between the population projection and the real data in 2006 is less than $1 \%$ in each region. In 2011, the projected value slightly exceeds the real one in Northern Great Plain and Northern Hungary, while in Central Hungary, the population number is underestimated. This points to the fact that the estimation was made with lower in-migration and fertility for Central Hungary and with lower out-migration and higher fertility for Northern Hungary and Northern Great Plain than the real trends were. 
In the divergence from the estimated migration, the economic crisis could play a role, which the population projection obviously could not reckon with.

\section{County level population projection}

After regions, the population projections for smaller territorial units are compared to the real trends. It is again well demonstrated in Figure 5 that the population increase in Central Hungary described in the foregoing is due to the growth in Pest county.

A significant population growth can be expected only in Pest county, while a slight one in Fejér and Győr-Moson-Sopron counties. The most drastic fall will occur in Békés county, where the population number will decrease by $22 \%$ compared to 1980 , while a nearly $20 \%$ population loss will occur in Tolna, Nógrád, Borsod-Abaúj-Zemplén counties and in Budapest according to the projections.

Figure 5

Probable change in population size between 1980 and 2021 by counties $(1980=100 \%)$

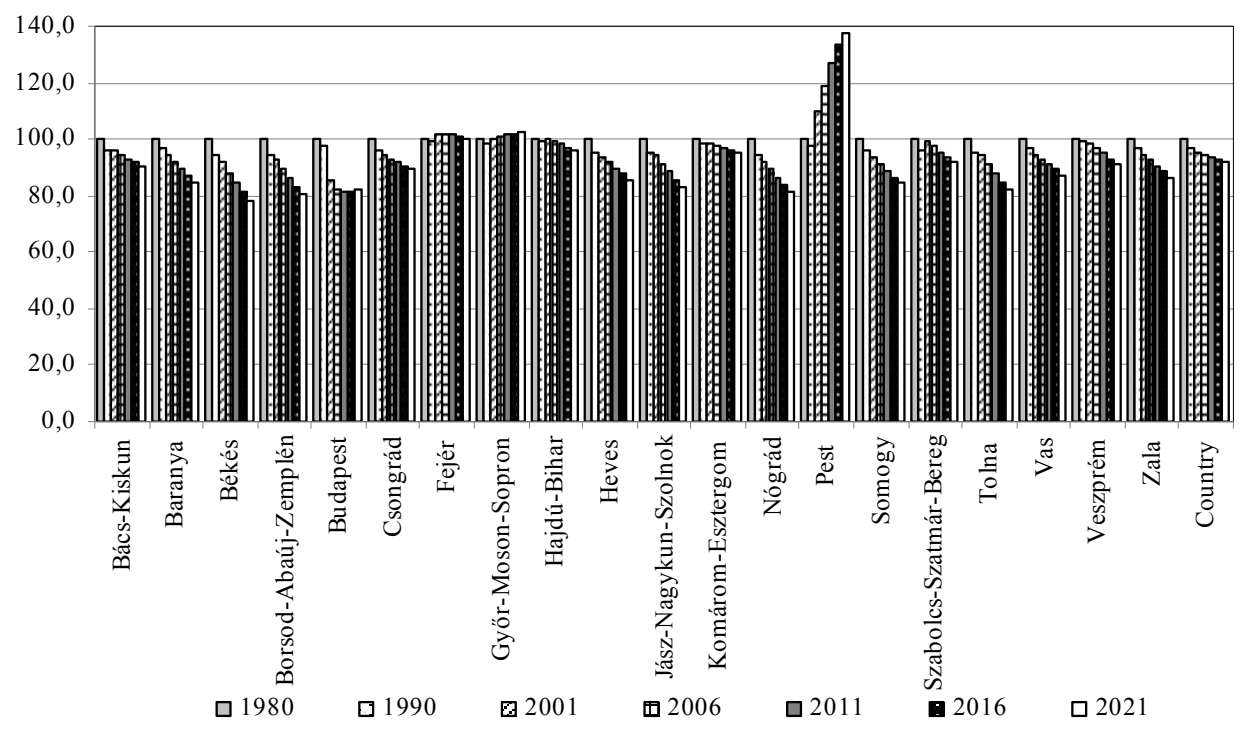

Source: Own calculation based on VÁTI TEIR.

The population projection for 2006 differs significantly from the real data only in two counties (the difference as a percentage of the population is more than $1 \%$ ): it was overestimated in Győr-Moson-Sopron county and underestimated in Veszprém county. 
Difference between real and projected population as a percentage of the population by counties

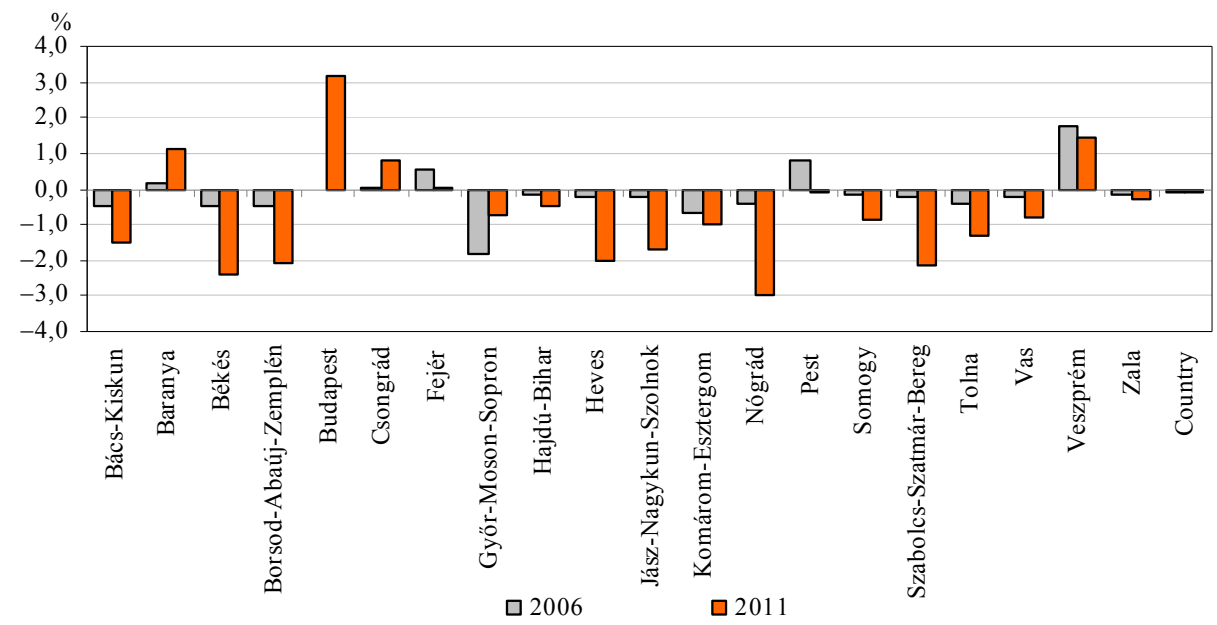

Source: Own calculation based on VÁTI TEIR.

In 2011, the difference exceeded $2 \%$ in five counties, only the population size of Budapest was underestimated by the projection model, while in case of Békés, Borsod, Nógrád and Szabolcs-Szatmár-Bereg counties, it was overestimated.

The economic crisis deepened inequalities, which brought large uncertainties into the system, and this also contributed to the fact that larger differences could be observed between projections and real population data of 2011. Projections cannot take into account the effects of such changes of course, especially for the reason that, even if these prevail for a relatively short period, demographic trends follow already a different line after the 'restoration'.

\section{Micro-regional population projection}

By examining population dynamics on micro-regional level, we can come to two conclusions. The population of most micro-regions is continuously decreasing, which is not surprising, as the tendency is similar for the population of the whole country. There are however 37 micro-regions, where the balance of population is positive, and in another 26 micro-regions, the population loss is lower than the national average. There are microregions in very good position, which belong to the catchment area of large cities and county seats. Eight micro-regions are in the direct catchment area of Budapest (Veresegyháza, Gödöllő, Érd, Budaörs, Szentendre, Pilisvörösvár, Ráckeve, Dunakeszi), and another eight micro-regions belong to the larger catchment area of the capital. From these micro-regions, Budapest is easily accessible within one hour. Although the Gárdony micro-region is not located in Central Hungary, the transport conditions are very good there as well, and according to projections, its population will increase by some one third by 2021 compared to 1980 . 


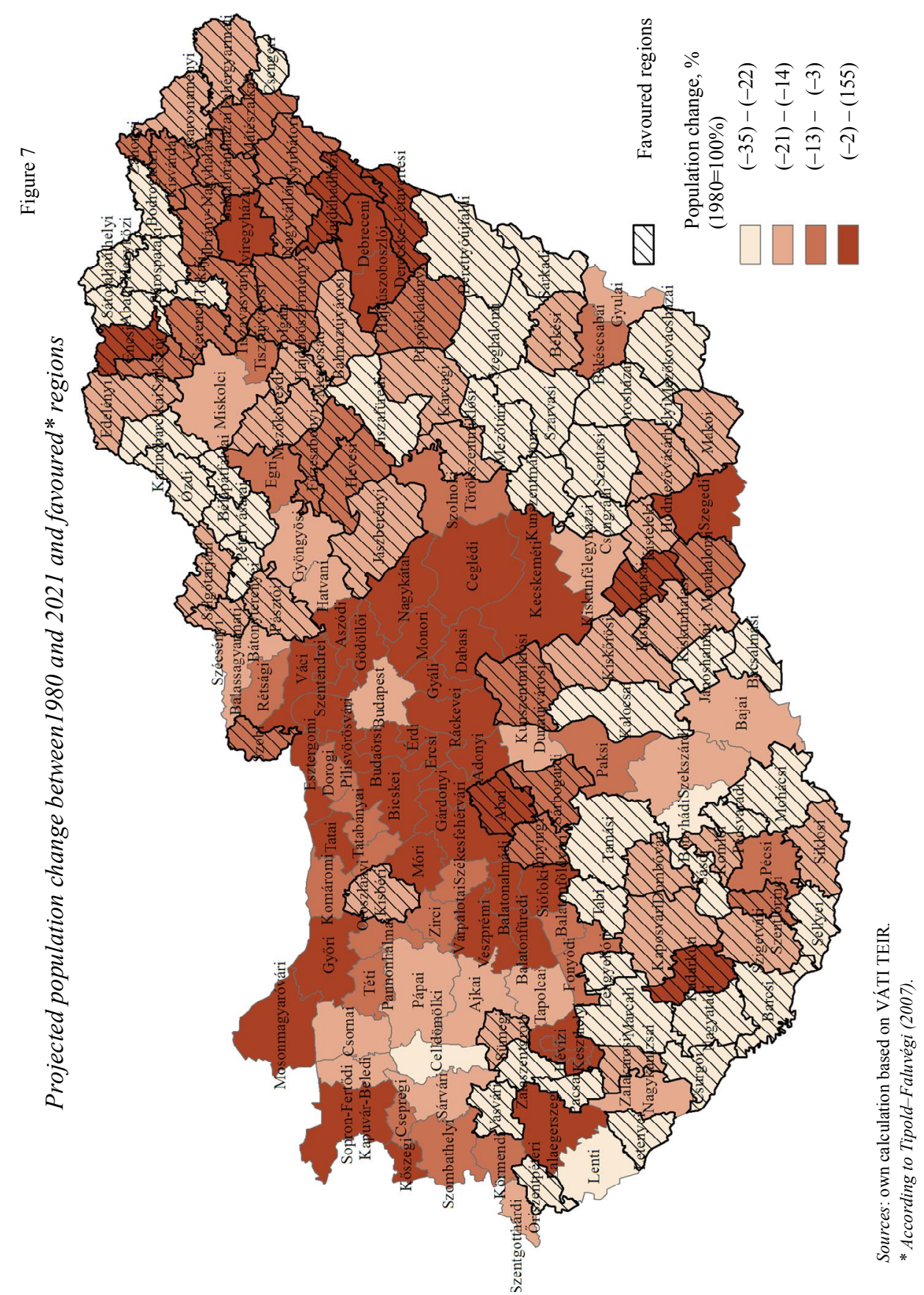


The other, much more sensitive issue of the study is the considerable population growth of micro-regions densely populated by Roma people, e.g. the micro-region of Hajdúhadház (25.3\%).

While in case of county seats and the agglomeration of Budapest, all demographic trends affect positively the population increase, i.e. the fertility rate, the balance of migration, the balance of natural increase/decrease and the age-structure are all favourable, in the micro-region Hajdúhadház, the population growth results only from the outstandingly high fertility rate, which offsets the effect of the negative trend in migration (Hablicsek 2007b).

$25.5 \%$ of the favoured micro-regions are in Northern Great Plain, 22.3\% in Northern Hungary, 20.2\% in Southern Great Plain, but this rate is nearly $20 \%$ in Southern Transdanubia as well with 18 favoured micro-regions. Central Hungary, Central Transdanubia and Western Transdanubia together account for only $12.8 \%$ of all favoured micro-regions. The serious situation in Northern Great Plain is also shown by the fact that $86 \%$ of all micro-regions of the region are favoured ones, i.e. out of the 28 microregions there, 24 belong to this category. The proportion of disadvantaged micro-regions is high is Southern Transdanubia, Northern Hungary and Southern Great Plain as well (72\%, $75 \%$ and $76 \%$, respectively).

\section{Micro-regional population projections and real data}

In 2006, the population projection on country level differed from the real population number only by $0.06 \%$. This difference was $0.1 \%$ in 2011 . Both values are negative, i.e. a smaller population decrease was assumed than the real trend was.

Table 4

Difference between real and projected data as a percentage of the population, 2006

\begin{tabular}{l|cll|c}
\hline \multicolumn{1}{c|}{ Micro-region } & Difference, $\%$ & & \multicolumn{1}{c}{ Micro-region } & Difference, \% \\
\cline { 1 - 2 } Gödöllöi & 1.08 & & Adonyi & -10.12 \\
Siófoki & 1.16 & & Balatonföldvári & 3.05 \\
Dunakeszi & 1.35 & & Salgótarjáni & 1.79 \\
Pilisvörösvári & 1.37 & & Bodrogközi & 1.07 \\
Budaörsi & 1.45 & & Mezötúri & 1.06 \\
Ráckevei & 1.49 & & Öriszentpéteri & 1.01 \\
Veresegyházi & 2.11 & & & \\
Bátonyterenyei & 2.35 & & &
\end{tabular}

Source: Own calculation.

Based on this indicator, the well separable groups of micro regions are as follows:

- In 2006, micro-regions, which surpassed expectations, i.e. where the population growth exceeded the projection by more than $1 \%$, were, apart from a few exceptions, dynamically developing regions belonging to the Budapest agglomeration. 
- Overestimated population number with a more than $1 \%$ difference was observed in 6 micro-regions; among them, the difference is striking, more than $10 \%$ in the Adony micro-region..

Table 5

Difference between real and projected data as a percentage of the population, 2011

\begin{tabular}{l|cll|c}
\hline \multicolumn{1}{c}{ Micro-region } & Difference, $\%$ & & \multicolumn{1}{c}{ Micro-region } & Difference, $\%$ \\
\cline { 1 - 2 } Ráckevei & 2.08 & & Kiskunmajsai & -15.52 \\
Nyíregyházai & 2.11 & & Adonyi & -14.75 \\
Sopron-Fertődi & 2.54 & & Bodrogközi & -8.62 \\
Székesfehérvári & 2.72 & & Füzesabonyi & -6.19 \\
Pécsi & 2.88 & & Polgári & -5.64 \\
Dunaújvárosi & 2.95 & & Bélapátfalvai & -5.60 \\
Veszprémi & 3.03 & & Sarkadi & -5.52 \\
Váci & 3.09 & & Mezökovácsházai & -5.48 \\
Budapest & 3.16 & & Mezócsáti & -5.45 \\
Szegedi & 3.22 & & Balatonföldvári & -5.44 \\
Debreceni & 3.27 & Szerencsi & -5.17 \\
Bátonyterenyei & 3.56 & Hevesi & -5.16 \\
Lengyeltóti & 4.14 & Salgótarjáni & -5.03 \\
Gárdonyi & 4.48 & &
\end{tabular}

Source: Own calculation.

In 2011, the projected population number in the catchment area of some big cities was less than the real data, while, first of all, in some micro-regions of Northern Hungary and Northern Great Plain overestimated population numbers can be observed. ${ }^{5}$

Thus, the above results indicate that the extent of migration towards larger towns is higher than the predicted trends. Due to lack of jobs, young people and those with higher educational attainment move probably to a larger extent to towns than it was expected by the projection. These are of course only assumptions, exploring the reasons and checking the hypotheses need further research.

Regional factors influencing population dynamics: educational attainment and the effect of the Roma population

In the opinion of Hablicsek (2006), regional differences will diminish in the following period due to the ,educational boom”. If it is true, the white micro-regions in Figure 8 will shift to the grey ones. In my opinion, however, the out-migration of people with higher educational attainment from disadvantaged regions will continue. Detailed migration data for analyzing the reason for migration, the educational attainment and age

5 The interpretation of micro-regional data and drawing the conclusion need however care. The composition of microregions is continuously changing (the number of micro-regions was 138 in 1994, 150 from 1997, 168 from 2004, 174 from 2007 and 175 from 1 January 2011), settlements were transferred from one micro-region to another or even from one county to another, which distors the results. Although differences deriving from the changes are tried to be homogenized in the VÁTI TEIR system, it does not work perfectly, and the long-range population projection does not naturally ccalculate with the separation of settlements (http://hu.wikipedia.org/ wiki/Kistérség). 
of migrants are unfortunately not available. My hypothesis is that those with higher educational attainment do not find a proper job in the disadvantaged regions, therefore, they settle down in towns or in their catchment areas. Thus, the "educational boom" induces not the decrease but just the increase of regional inequalities, i.e. regions suffering considerable population loss will be faced with further depopulation. The scientific literature has already indicated this trend, since, in contrast with all previous expectations, regional inequalities rather increase than diminish (Spéder 2002, Kulcsár 2009, Bódi 2010).

The correlation between educational attainment and belonging to the Roma population is of course very close. It is well known that the educational attainment of the Roma population is by far below that of the non-Roma population (Polónyi-Tímár 2006). In the regions afflicted by the crisis, the proportion of the Roma population is outstandingly high. On the one hand, this was explained by the fact that out-migrants with higher educational attainment have better chances to find a job in case of outmigration as well. The educational attainment of the Roma population is generally lower, so they would find a job with more difficulties even if they moved, therefore, they rather stay. On the other hand, in regions with declining economy, their chances for outmigration are worse due to the lower property prices, while these regions may be therefore attractive in respect of settling. All these result in the increase in the proportion and the concentration of the Roma population in these economically underdeveloped regions (Kertesi-Ábrahám 1996).

Projection of proportion of people with at least secondary educational attainment

Figure 8 (for 2021) in the micro-regions of Hungary

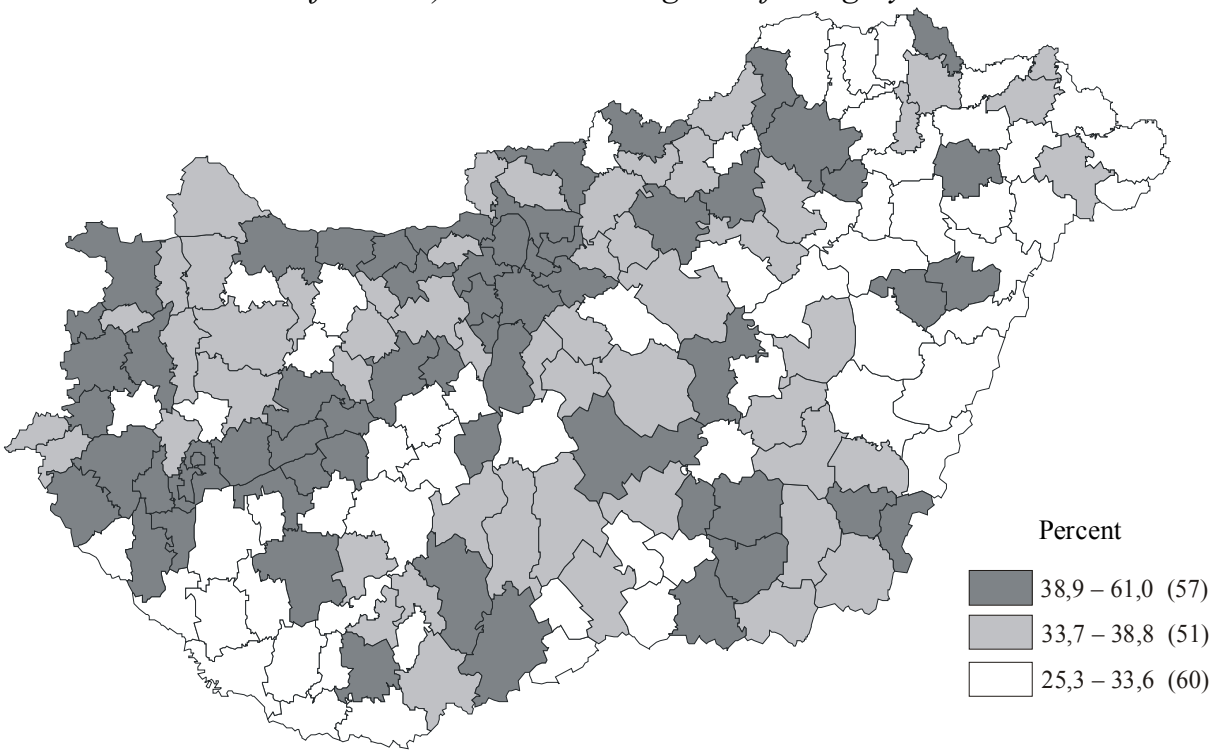

Sources: Hablicsek (2007a). 
The projections of László Hablicsek covered the estimation of the proportion of the Roma population as well. This is shown in Table 6.

Number and proportion of Roma population between 1991and 2021

Table 6

\begin{tabular}{l|r|r|r|r|r|r|r|r}
\hline \multirow{2}{*}{ Region } & \multicolumn{3}{|c|}{$\begin{array}{c}\text { Estimated number of Roma } \\
\text { population, thousand persons }\end{array}$} & \multicolumn{3}{c}{ Proportion of Roma population, \% } \\
\cline { 2 - 8 } & \multicolumn{1}{|c|}{1991} & \multicolumn{1}{c}{2001} & \multicolumn{1}{c}{2011} & \multicolumn{1}{c}{2021} & 1991 & 2001 & 2011 & 2021 \\
\hline Budapest & 40.4 & 59.6 & 80.5 & 103.2 & 2.0 & 3.4 & 4.8 & 6.1 \\
Central Hungary & & & & & & & & \\
without Budapest & 65.8 & 97.0 & 132.7 & 173.0 & 2.2 & 3.4 & 4.6 & 5.7 \\
Central Transdanubia & 22.8 & 31.0 & 39.8 & 49.5 & 2.1 & 2.8 & 3.6 & 4.6 \\
Western Transdanubia & 22.2 & 26.4 & 30.2 & 33.7 & 2.2 & 2.6 & 3.0 & 3.5 \\
Southern Transdanubia & 63.5 & 72.4 & 79.3 & 84.9 & 6.3 & 7.3 & 8.4 & 9.6 \\
Northern Hungary & 123.8 & 151.5 & 181.9 & 215.5 & 9.4 & 11.6 & 14.9 & 18.8 \\
Northern Great Plain & 114.5 & 129.6 & 145.0 & 161.3 & 7.4 & 8.3 & 9.6 & 11.2 \\
Southern Great Plain & 35.5 & 41.8 & 48.7 & 56.3 & 2.5 & 3.0 & 3.7 & 4.4 \\
Hungary, total & 448.1 & 549.7 & 657.6 & 774.2 & 4.3 & 5.4 & 6.6 & 7.9 \\
Change on country level, \%, & & & & & & & &
\end{tabular}

Source: Hablicsek (2007b), own calculation.

According to the projection of László Hablicsek, the population number will be around 9 million by 2050 , of which the Roma population will be one million, i.e. $11 \%$ of the population will belong to the Roma minority. He estimated the number of immigrants at one million as well. In the baseline variant, the increase in the Roma population shows a declining trend, and the decrease in the number of the country's population will probably decelerate as well.

Along with this, the proportion of the Roma population in the total population will continue to grow ${ }^{6}$, and by 2050 it may reach or exceed 12\% (Polónyi-Tímár 2006, Hablicsek 2007b).

In three regions, i.e. in Northern Hungary, Northern Great Plain and Southern Transdanubia, the high proportion of disadvantaged micro-regions and the high proportion of Roma population prevail in parallel. The exception is Southern Great Plain, where the proportion of disadvantaged micro-regions is high (more than $20 \%$ ), but the proportion of Roma population is quite low (4.44\%).

\section{Socio-economic development and population dynamics}

Demographic trends are partly the reasons and partly the consequences of the socioeconomic situation of a region. Researchers often assume significant correlation between the state of development and the age-structure of a region. The generally accepted opinion is that in underdeveloped settlements and regions with limited resources and services the old-age dependency ratio is increasing. 
However, it can be demonstrated that the favourable age-structure is not by all means accompanied with advanced socio-economic development. In some micro-regions of Hungary, the disadvantaged situation and underdevelopment is coupled with favourable age-structure. In other ones, the good geographical position (it is near a town, there are tourist attractions, etc.) partly offsets the unfavourable age-structure and the demographic disadvantage.

Migration is one of the most important indicators of regional socio-economic inequalities. Migration from the less developed regions to the more developed ones is induced among others by the better job opportunities (Teaford 2008, Brown-Glasgow 2008). However, this situation has to be examined with a more tinged approach. Some disadvantaged regions are characterized by the ageing of the population and outmigration, while in others the situation is just the opposite. Thus, it is not true in all instances that in underdeveloped regions the population is ageing and they are left by young people, while the developed ones are always characterized by increasing population and young age-structure.

Hereinafter, I will examine the correlation of the features of the age structure with the population projection and the socio-economic development. I present a typology, which pictures the relation between the dynamics of the age-structure and the economic development which is not simple at all.

As a first step of the multivariate statistical analysis, I applied a variance reduction method, the principal component analysis (PCA) ${ }^{7}$ in order to define the main socioeconomic characteristics. In the second step, by involving the resulted principal components I grouped the micro-regions by a cluster analysis. ${ }^{8}$

Table 7

Rotated component matrix

\begin{tabular}{|c|c|c|}
\hline Indicators & $\begin{array}{l}\text { 1st principal component: } \\
\text { economic force }\end{array}$ & $\begin{array}{c}\text { 2nd principal component: } \\
\text { young population }\end{array}$ \\
\hline In- and out-migration, $\%{ }^{\text {a) }}$ & 0.907 & 0.119 \\
\hline Number of enterprises per 1,000 inhabitants $^{\text {a) }}$ & 0.903 & 0.065 \\
\hline Unemployment rate $^{\text {b) }}, \%^{\text {a) }}$ & -0.860 & 0.281 \\
\hline Logarithm of income/capita ${ }^{\text {a) }}$ & 0.855 & -0.106 \\
\hline Population change, $\%{ }^{c)}$ & 0.836 & 0.418 \\
\hline Change in dwelling stock $\%$ c) & 0.835 & 0.304 \\
\hline Proportion of new dwellings, $\%{ }^{\text {a) }}$ & 0.833 & 0.307 \\
\hline Number of passenger cars per 100 persons ${ }^{\text {a) }}$ & 0.790 & -0.414 \\
\hline Population density, persons $/ \mathrm{km}^{2 \mathrm{a})}$ & 0.697 & 0.304 \\
\hline Proportion of population under 14 years of age, $\%{ }^{a)}$ & -0.234 & 0.931 \\
\hline Birth rate per 1,000 persons $^{\text {a) }}$ & 0.001 & 0.888 \\
\hline Old-age dependency ratio, $\%{ }^{a)}$ & -0.243 & -0.817 \\
\hline Number of persons per households ${ }^{\mathrm{a})}$ & 0.289 & 0.790 \\
\hline
\end{tabular}

Source: Own calculation.

a) In 2009. b) Proportion of jobseekers in the population aged 18-65 years. c) 2009/2001.

7 For more details about the method see Bartók (1983), Francia (1976) és Czirfusz (2010).

8 I worked with the data of the VÁTI TEIR system in the analysis. 
The KMO value (how the variables fit in the model) is 0.839 , which shows that the variables involved in the analysis fit well in the PCA model. In the applied principal component analysis, the total variance explained is $78.3 \%$, if only eigenvalue components higher than one are taken into account. Two principal components meet this requirement. After rotation (applying varimax rotation), the variance explained by the first principal component is $50 \%$, while the explanatory value of the second factor is $28.3 \%$

The first two strongest variables are the in-migration/out-migration ratio and the number of enterprises per 1,000 persons. The correlation between the principal component and the variables is very strong. In the first principal component, the third strongest variable is the unemployment rate, which is connected with negative sign to the principal component. There are some further demographic and economic indicators in the first principal component, therefore, I named this factor as 'economic development' factor.

The second factor correlates the best with the proportion of young people. The oldage dependency ratio is connected with a negative, while the birth rate is connected with a positive sign to this factor. Therefore, this factor could be named as 'young population' factor. Based on the results, we can say that the factors can be unambiguously identified and are suitable for further analysis.

In Table 8, micro-regions having extreme factor values are highlighted.

Table 8

Micro-regions with extreme factor values

\begin{tabular}{l|c|c}
\hline \multicolumn{1}{c|}{ Micro-region } & Economic development & Young population \\
\hline Öriszentpéteri & 0.18 & -2.69 \\
Hévízi & 1.27 & -2.03 \\
Gödöllöi & 2.27 & 1.35 \\
Monori & 2.06 & 1.32 \\
Ráckevei & 2.51 & 1.73 \\
Budaörsi & 3.63 & 1.87 \\
Dunakeszi & 3.84 & 2.09 \\
Pilisvörösvári & 2.28 & 1.44 \\
Szentendrei & 2.23 & 0.95 \\
Veresegyházi & 3.06 & 2.61 \\
Érdi & 2.69 & 1.47 \\
Hajdúhadházi & -0.62 & 2.49 \\
Edelényi & -1.46 & 2.13 \\
Encsi & -1.22 & 2.49 \\
Szikszói & -1.25 & 2.04 \\
Baktalórántházai & -1.17 & 2.08
\end{tabular}

Source: Own calculation.

Among micro-regions having extreme values, there are economically developed, dynamically developing ones with young population near Budapest (Gödölli, Monor, Ráckeve, Budaörs, Dunakeszi, Pilisvörösvár, Szentendre, Veresegyháza, Érd) on the one hand and economically underdeveloped micro-regions having however young population (Hajdúhadház, Edelény, Encs, Szikszói, Baktalórántháza micro-regions, where the proportion of Roma population is high) on the other. The third group is made up by the 
Hévíz micro-region with high proportion of old population but with quite good economic potential and by the Öriszentpéter micro-region with moderate economic conditions.

In order to create a micro-regional typology based on the correlation of the two examined factors, I made a cluster analysis on the factors. As a result of the cluster analysis based on the factor values, micro-regions are divided in four groups. The cluster centre values for the two factors are included in Table 9, while Figure 9 shows the location of the clusters.

Table 9

Cluster centres

\begin{tabular}{l|l|l|l|c}
\hline \multirow{2}{*}{\multicolumn{1}{c|}{ Factors }} & \multicolumn{4}{|c}{ Cluster } \\
\cline { 2 - 5 } & 1 & 2 & 3 & 4 \\
\hline Economic development & $-0,212$ & 2,730 & 0,777 & $-0,978$ \\
Young population & $-0,770$ & 1,647 & 0,050 & 1,110 \\
Number of micro-regions & 81 & 9 & 42 & 41
\end{tabular}

Source: Own calculation.

Figure 9

Location of micro-regional clusters in the factor space

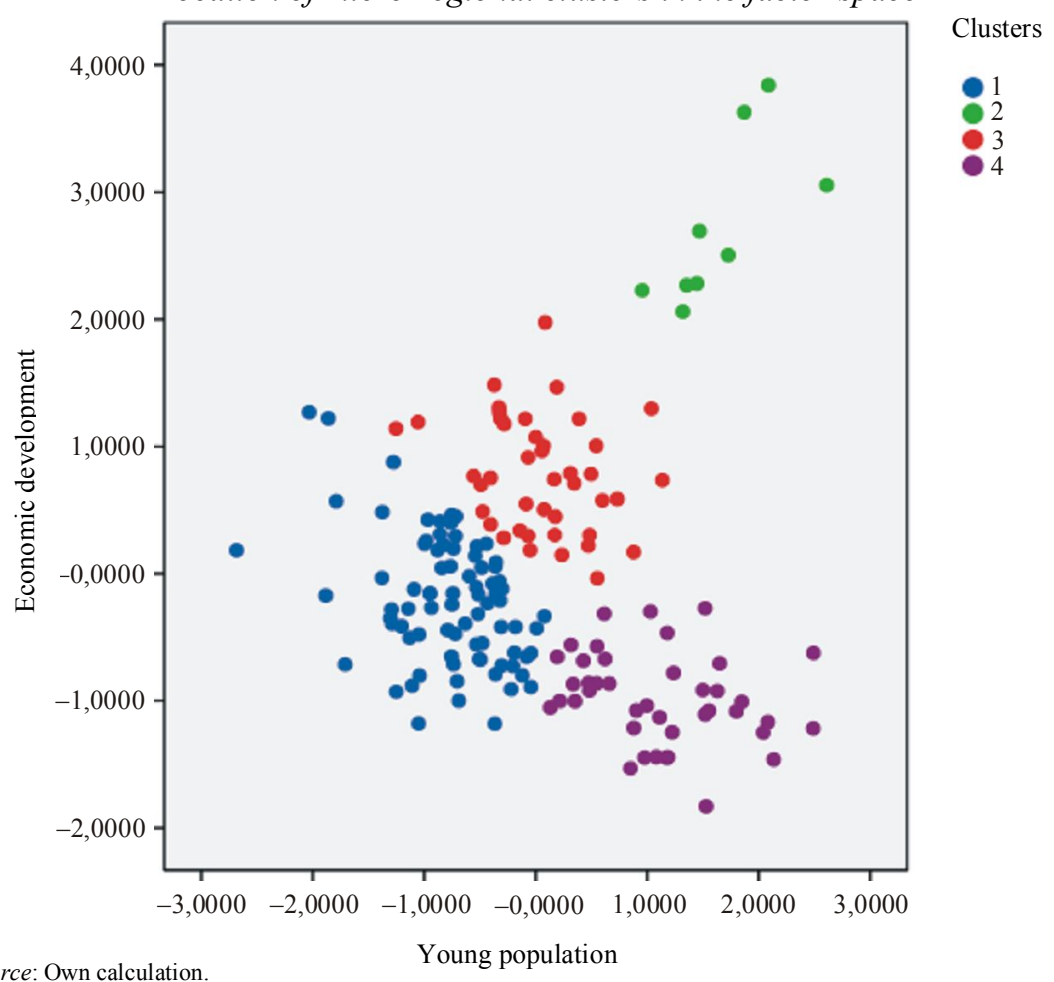

The aim of the cluster analysis ${ }^{y}$ is to group the micro-regions by their economic force and age-structure. As a first step, I performed a hierarchical cluster analysis, then, I 
applied K-mean method. Finally, after comparing the results, I accepted the cluster result of the K-mean method as final.

Based on the cluster centres, the groups can be characterized. It is well shown in the table that the fourth cluster is characterized by a favourable age-structure and young population, but it is comprised of micro-regions with the most underdeveloped economy. At the same time, in the second cluster, the favourable age-structure is accompanied by the strongest economic development. The poor, ageing micro-regions belong to the first cluster, while the ones slightly more developed than the average and having mediumlevel age-structure are in the third cluster.

The differences in the features of the clusters are shown by their spatial locality along the cluster axis (Figure 10).

As it shown in Figure 10, there are large differences among the clusters in respect of both age-structure and economic development. The situation is the best in the second cluster; these micro-regions are located in the agglomeration around Budapest. They are dynamically developing micro-regions with high population density, low unemployment rate, strong economy and favourable demographic characteristics.

Location of the clusters along the factors

Figure 10
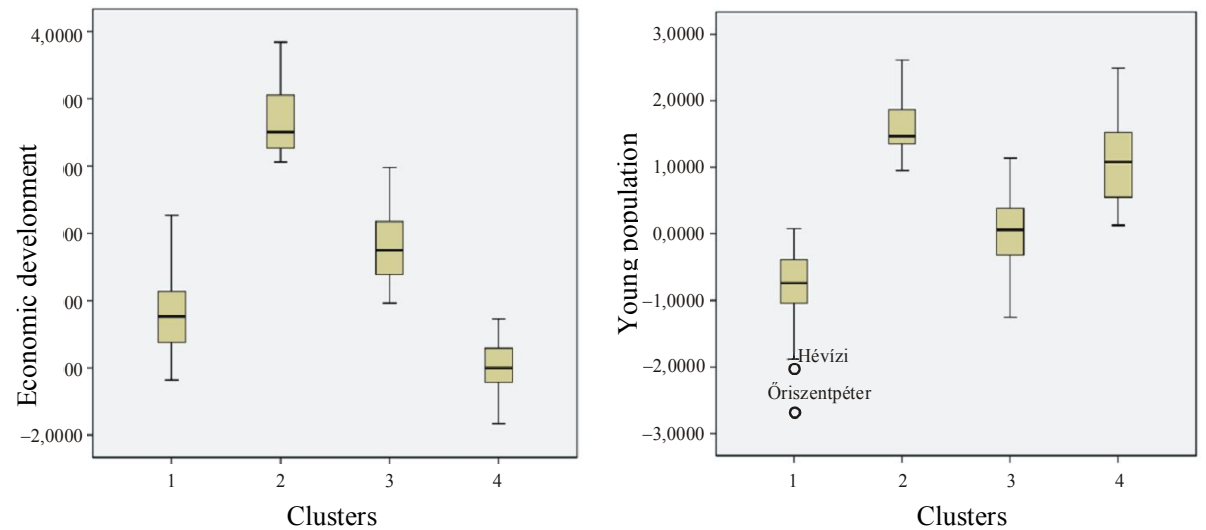

Source: Own calculation

The fourth cluster is the other special group of micro-regions with highly underdeveloped economy and very young age-structure. This group comprises the most problematic micro-regions: there are no job opportunities, the level of educational attainment is low, while the unemployment rate and the proportion of long-term unemployed are high. The birth rate is especially high and the fertility rate is much higher than in the other regions. However, while the fertility and birth rates are outstandingly high, life expectancy at birth is lower than in the other parts of the country (Hablicsek 2009).

The geographical location of the clusters is shown in Figure 11.

Micro-regions with the youngest population are basically located in four regions of the country. The largest contiguous areas are in the north-eastern part of the country, mainly micro-regions in Borsod-Abaúj-Zemplén and Szabolcs-Szatmár-Bereg counties 
as well as in the agglomeration around the capital city are here. There are two another areas which are characterized by young population: one in Baranya county, along the Dráva and the other in the middle part of Northern Great Plain. However, the favourable age-structure is not always accompanied with economic development. In some microregions, the relation between the age-structure and the economic performance is positive, while in others it is negative. Economic development is the strongest in the central part of the country and in the northern part of Transdanubia.

Figure 11

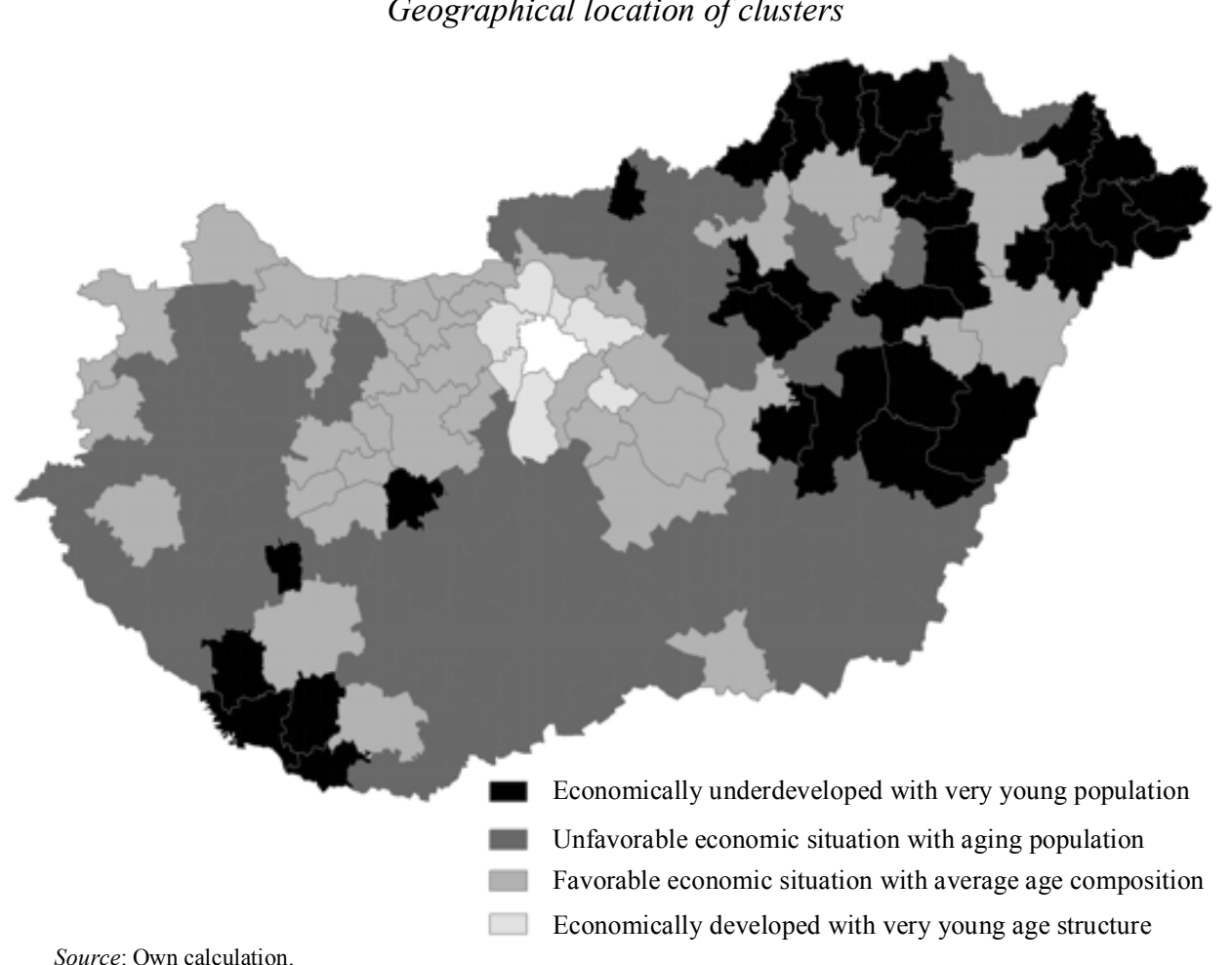

Micro-regions in unfavourable economic situation and with young population are located in Southern Transdanubia and Northern and Eastern Hungary.

\section{Population dynamics and projection of clusters}

The population dynamics of the four established homogeneous groups show considerable differences as well. When examining the period between 1980 and 2011, we can see that, among the four groups, population dynamics is by far the strongest in the economically developed micro-regions around Budapest having favourable socio-economic characteristics and young age-structure. On the whole, considerable population loss is characteristic of the first and the fourth group, with the exception of some micro-regions, 
such as the Hajdúhadház micro-region in the economically underdeveloped group having however a young age-structure.

The socio-economic situation of the third cluster can be considered good, since its population loss equals the national average or lower, and some micro-regions (e.g. Gárdony) have a considerably positive population balance. It can be seen in Figure 12 that, in respect of population dynamics, the situation is the same in the first and the fourth cluster, while it is significantly better in the third and the second one. The population is decreasing in the first and the fourth cluster, it is stagnant in the third one - having however better value than the country average - while the population of the second cluster comprising only nine micro-regions is dynamically increasing.

Figure 12

Population dynamics in the micro-regions of the clusters

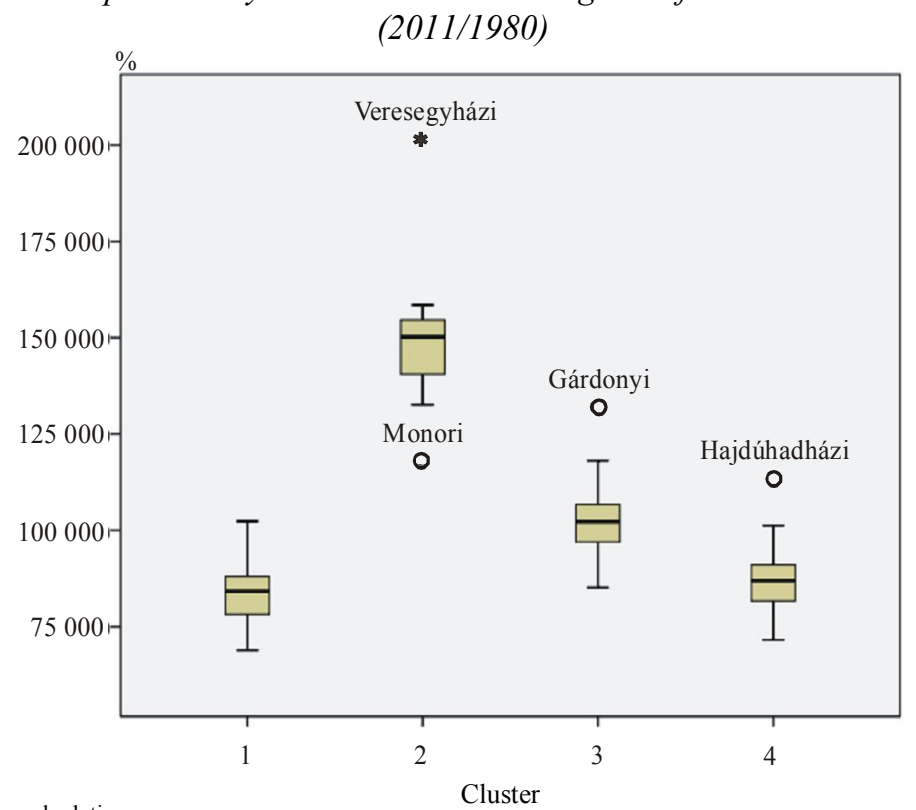

Source: Own calculation.

Figure 13 shows how the real population dynamics data differ from the projections in each cluster.

The first cluster is the economically underdeveloped group with ageing population. The projection predicted a higher population number than the real number was. This cluster is characterized by a strong population decrease exceeding the projected one.

The second cluster includes the most developed micro-regions around Budapest with very young age-structure. In this group, the real population number is higher than the projected value, i.e. the population concentration is stronger than it could be deduced from the projection. The larger in-migration from the country and immigration from abroad, the outstanding fertility rate surpassed the expectations. In 2011, this cluster could record significant population surplus compared to 1980 . 
The third cluster comprises the moderately developed micro-regions with average age-structure. In 2006, the projection was completely accurate, but by 2011, the population number was higher than projected. The population of the micro-regions comprising the cluster is basically stagnant, so it is characterized by positive demographic trends compared to the national trend.

The population of the fourth cluster is decreasing except for the Hajdúhadház microregion. The population projection predicted a considerably larger population for this group with very underdeveloped economy but with outstandingly high fertility rate. This also shows indirectly that the population increase moderates among groups with high fertility as well.

Figure 13

Differences between real population number and projected population data in the clusters

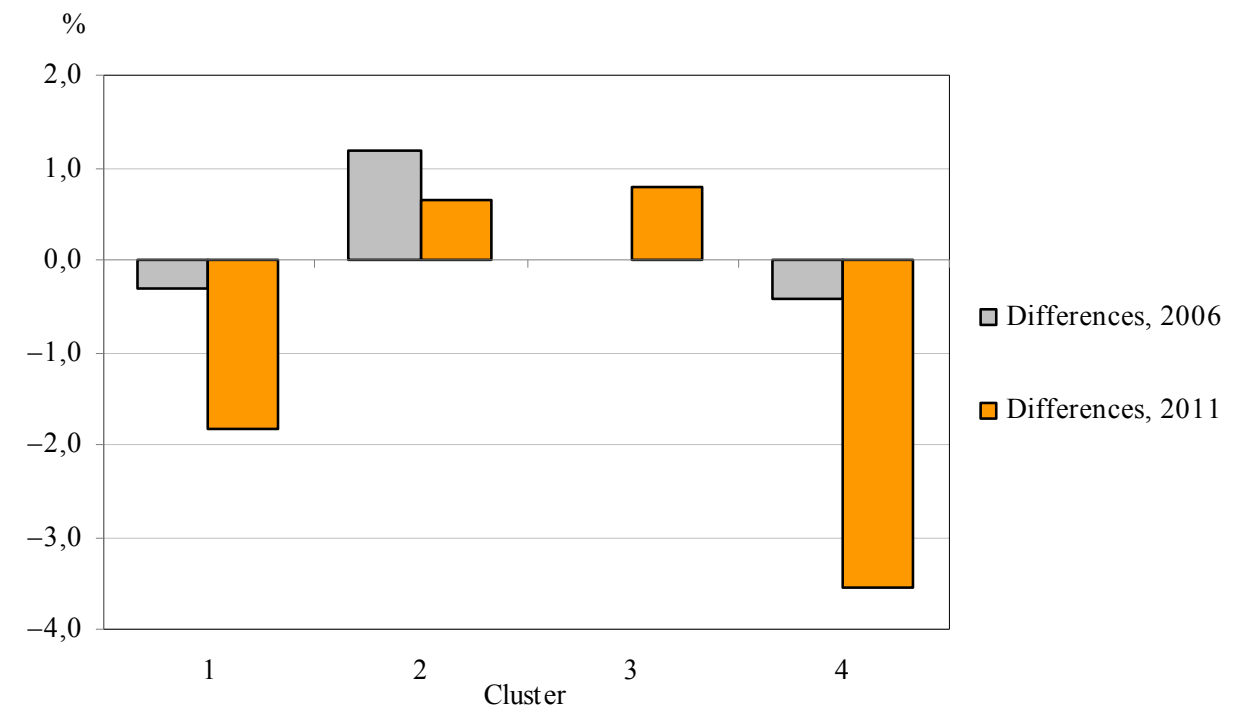

Source: Own calculation.

REFERENCES

Bartók János (1983): Faktoranalízis a gyakorlatban. TK Mühely, 2. (Factor analysis in practice)

Bódi Ferenc (2010): Népességfogyás, a szegénység ördögi köre. A Falu, 3. (Population decrease, the vicious circle of poverty)

Brown, David L. - Nina Glasgow (2008): Rural Retirement Migration. Springer

Czirfusz Márton (2010): Faktoranalízis, a látszatmegoldás. Tér és Társadalom, 1. (Factor analysis, a pseudosolution)

Francia László (1976): A faktoranalízis és alkalmazása területi vizsgálatokban. In: Kulcsár Viktor (szerk.): A regionális elemzések módszerei. Akadémia Kiadó, Budapest (Factor analysis and its application in regional research)

H. Richter Mária (2002): A népesség becslése évközi időpontokra. A kanadai népesség-továbbszámítási modell adaptációja. Demográfia, 2-3. (Population projection for reference dates. An adaptation of Canadian population estimation model) 
Hablicsek László (2000): Kísérlet a roma népesség előreszámítására 2050-ig. In: Horváth Ágota et al. (szerk.): Cigánynak születni. Tanulmányok, dokumentumok. Aktív Társadalom Alapítvány \& Új Mandátum Kiadó, Budapest (Experimental calculations for the projection of the Roma population till 2050)

Hablicsek László (2001): A népességreprodukció alakulása a 20-21. században. KSH NKI, Budapest (The reproduction of Hungary's population in the $20^{\text {th }}-21^{\text {st }}$ centuries)

Hablicsek László (2006): A népesség várható alakulása a következő évtizedekben, különös tekintettel a területi különbségekre. In: Tausz Katalin (szerk.): A társadalmi kohézió erősítése. ÚMK Budapest (Population prospects in the next decades with special respect to the spatial differences)

Hablicsek László (2007a): Népességünk következő évtizedei - különös tekintettel a területi különbségekre. Demográfia, 4. (Next decades of our population with special respect to the spatial differences)

Hablicsek László (2007b): Kísérleti számítások a roma lakosság területi jellemzőinek alakulására és 2021-ig történő előrebecslésére. Demográfia, 1. (Experimental calculations for the spatial characteristics of the Roma population and its projection till 2021)

Hablicsek László (2009): A népesség szerkezete és jövője. Demográfiai portré. Jelentés a magyar népesség helyzetéről. KSH NKI, Budapest (Structure and future of the Hungarian population)

http://fogalomtar.eski.hu/index.php/Népesség-elöreszámítás

Kertesi Gábor - Ábrahám Árpád (1996): A munkanélküliség regionális egyenlőtlenségei Magyarországon 1990 és 1995 között. Közgazdasági Szemle, július-augusztus (Regional inequalities of unemployment in Hungary between 1990 and 1995)

Kulcsár László (2009): Társadalmi zárványok, vagy zárványtársadalmak? Területi Statisztika, 1. (Social enclaves or enclave societies?)

www.nepszamlalas2001.hu

Obádovics Csilla - Popovics Attila (2011): Klaszteranalízis. Melyiket válasszam? „Hitel, Világ, Stádium”. Nemzetközi konferencia. 2010. november 3. Sopron, Konferencia kiadvány (CD kiadvány 2011) (Cluster analysis: How to choose?)

Polónyi István - Tímár János (2006): Oktatáspolitika és demográfia. Felsőoktatási Kutatóintézet, Budapest (Educational policy and demographics)

Spéder Zsolt (2002): A szegénység változó arcai. Tények és értelmezések. Századvég (The changing faces of poverty. Facts and meanings)

Teaford, Jon C. (2008): The American Suburb. The Basics. Routledge, New York

Tipold Ferenc - Faluvégi Albert (2007): Tájékoztató a területfejlesztés kedvezményezett térségei besorolásánál alkalmazott mutatókról és a számítás módszeréröl. A 67/2007. (VI. 28.) OGY határozat és a 2007. évi CVII. törvénnyel módosított 2004. évi CVII. törvény alapján. Budapest (Information on the applied indicators for classification of favoured areas of regional development and the calculation method). 